\title{
PERBEDAAN ANTARA BERAT BADAN SEBELUM DAN SESUDAH MENGGUNAKAN KB SUNTIK TIGA BULAN DI PUSKESMAS KOM YOS SUDARSO KOTA PONTIANAK PERIODE 2016 - 2017
}

\author{
Yuliana $^{1}$, Chahyani Erlita ${ }^{2}$
}

\author{
Akademi Kebidanan Panca Bhakti Pontianak \\ Email Korespondensi: akbidpbpontianak@gmail.com
}

\begin{abstract}
Abstrak
KB Suntik Tiga Bulan adalah kontrasepsi yang diberikan setiap tiga bulan sekali, mengandung 150 mg DMPA, Berdasarkan hasil studi pendahuluan yang dilakukan peneliti di Puskesmas Kom Yos Sudarso Kota Pontianak Tahun 2017, jumlah akseptor KB aktif tahun 2016 sejumlah 354 jiwa. Tujuan penelitian ini adalah untuk mengetahui adakah perbedaan antara berat badan sebelum dan sesudah menggunakan KB Suntik tiga bulan di Puskesmas Kom Yos Sudarso Kota Pontianak Periode 2016-2017. Desain penelitian yang digunakan adalah analitik komparatif dengan Pendekatan retrospektif dengan 78 responden untuk dijadikan sampel di Puskesmas Kom Yos Sudarso Kota Pontianak Tahun 2017. Hasil penelitian univariat berat badan sebelum penggunaan KB diketahui dari 78 akseptor yang menggunakan KB suntik tiga bulan berat badan yang paling tinggi $69 \mathrm{~kg}(1,3 \%)$, berat badan paling rendah $35 \mathrm{~kg}(1,3 \%)$, berat badan yang terbanyak $50 \mathrm{~kg}(9,0 \%)$, dan sesudah penggunaan berat badan yang paling tinggi $73 \mathrm{~kg}(1,3 \%)$, berat badan yang paling rendah $38 \mathrm{~kg}(2,6 \%)$ dan yang paling banyak 52 $\mathrm{kg}(14,1)$. Hasil bivariat rata-rata sebelum diberi suntikan $\mathrm{KB}$ adalah $(48,67 \mathrm{~kg})$ dan rata-rata sesudah diberikan suntikan $\mathrm{KB}$ adalah $(52,77 \mathrm{~kg})$. Maka dapat diambil kesimpulan bahwa ada perbedaan berat badan akseptor sebelum dan sesudah penggunaan KB suntik tiga bulan di Puskesmas Kom Yos Sudarso Tahun 2016 dimana $p$ value $=0,000$ yang berati ada perbedaan dan sesuai dengan teori yang ada. Saran untuk tenaga kesehatan di Puskesmas Kom Yos Sudarso agar memberikan penyuluhan terhadap pasangan usia subur (PUS) untuk memilih alat kontrasepsi yang tepat agar dapat dijadikan dasar pertimbangan dalam penapisan pada calon akseptor KB baru suntik tiga bulan.
\end{abstract}

Kata Kunci: Perbedaan, Berat Badan, Sebelum dan Sesudah, KB suntik 3 bulan

\section{Pendahuluan}

Laju pertumbuhan penduduk disuatu Negara dipengaruhi oleh tingkat kelahiran yang secara langsung akan berdampak pada jumlah penduduk. Menurut Badan Koordinasi Keluarga Berencana Nasional (BKKBN) pertumbuhan penduduk di Indonesia semakin tahun semakin bertambah jumlahnya, yaitu sebanyak 237656363 jiwa pada tahun 2010 dengan rata-rata kenaikan jumlah penduduk setiap 10 tahun sebesar 16-20\% (Burton, 2010).

Upaya pengendalian tingkat kelahiran di Indonesia di atur dalam sasaran Rencana Pembangunan Jangka Menengah Nasional (RPJMN) tahun 2014-2019 yang menargetkan

\footnotetext{
${ }^{1}$ Dosen Akademi Kebidanan Panca Bhakti Pontianak

${ }^{2}$ Dosen Akademi Kebidanan Panca Bhakti Pontianak
}

tingkat kelahiran secara Nasional pada tahun 2019 hanya mencapai angka 2,28 per wanita usia subur (Susenas, 2016). Tingkat kelahiran yang tinggi disebabkan oleh masih besarnya jumlah pasangan usia subur (PUS). Berdasarkan laporan statistik Family Planing World Wide (FPWW) tahun 2008 jumlah wanita subur (WUS) di Indonesia paling tinggi di bandingkan negara ASEAN lainnya, di ikuti Negara Vietnam dan Filipina adalah Timor Laste (Kemenkes RI, 2013).

Keluarga Berencana (KB) merupakan salah satu program yang dilakukan di Indonesia untuk mengatur jumlah kelahiran wanita usia 
subur serta menyelamatkan kesehatan ibu dan anak dengan berbagai alat kontrasepsi yang di sarankan dengan kondisi kesehatan ibu (Kemenkes RI, 2014). Keberhasilan pelayanan KB di Indonesia dalam kondisi stagnan Pencapaian penggunaan KB di Indonesia tahun 2012 sebesar 57,9\% tergolong rendah belum mencapai target RPJMN untuk cara modern sebesar $60,1 \%$ atau target millennium development goals (MDGs) sebesar 65\% (SDKI, 2012).

Kontrasepsi merupakan suatu cara untuk mencegah terjadinya kehamilan. Terdapat 9 jenis metode kontrasepsi yaitu metode keluarga berencana alamiah (KBA), metode amenorea laktasi (MAL), metode keluarga berencana alamiah (KBA), senggama terputus (koitus interruptus), metode barrier (kondom, diafragma, dan spermisida), kontrasepsi suntik, kontrasepsi oral (pil), alat kontraksepsi bawah kulit (AKBK)/implan, alat kontrasepsi dalam rahim (AKDR) dan kontrasepsi mantap (tubektomi dan vasektomi) (Prawirohardjo, 2010).

Berdasarkan data badan kependudukan dan KB nasional (BKKBN) menunjukkan bahwa pada tahun 2013 terdapat 8500247 (PUS) yang merupakan peserta KB baru dimana sebanyak 4.185115 (48,56\%) menggunakan kontrasepsi suntik tiga bulan (BKKBN, 2014). Berdasarkan data BKKBN tahun 2012 untuk peserta KB aktif di Provinsi Kalimantan Barat sebanyak 33.278 akseptor. Dengan rincian jumlah akseptor KB suntik 16,523 akseptor (49,65\%), Pil 13,052 akseptor (39,22\%), Kondom 4.304 akseptor (12,93\%), intra uterine device (IUD) 1.192 akseptor (3,58\%), Implan
925 akseptor $(2,77 \%)$, metoda operasi wanita (MOW) 128 akseptor $(0,38 \%)$, metoda operasi pria (MOP) 1 akseptor $(0,003 \%)$ (BKKBN Provinsi Kalbar, 2012).

KB Suntik Tiga Bulan atau Depo Medroksiprogesteron Asetat adalah kontrasepsi yang diberikan setiap tiga bulan sekali dengan cara di suntik Intramuskular (di daerah bokong), mengandung 150 mg DMPA, dengan efektivitas tinggi 0,3 kehamilan per 100 perempuan per tahun, dengan cara kerja yaitu menekan ovulasi, mengentalkan lendir seviks sehingga penetrasi sperma terganggu, perubahan pada endometrium (atrofi) sehingga implantasi terganggu, dan menghambat transportasi gamet oleh tuba (Affandi, 2011).

Pemberian kontrasepsi suntikan tiga bulan sering menimbulkan efek samping seperti gangguan haid (amenorea), yang bersifat sementara dan sedikit sekali mengganggu kesehatan, peningkatan berat badan, sakit kepala dan nyeri payudara. Efek samping ini biasanya dapat hilang dengan cepat dan tidak berbahaya (Arum, 2009).

Masalah peningkatan berat badan pada penggunaan $\mathrm{KB}$ suntik berdasarkan survei demografi dan kesehatan Indonesia (SDKI) tahun 2007 adalah sebesar 2,6\% peningkatan berat badan pada akseptor KB suntik tiga bulan umumnya tidak terlalu besar yaitu bervariasi antara $>1 \mathrm{~kg}-5 \mathrm{~kg}$ dalam tahun pertama penggunaan (Heritanto, 2004).

Penelitian yang dilakukan University of Texas Medical Branch (UTMB) menyatakan rata-rata peningkatan berat badan ibu akseptor $\mathrm{KB}$ suntik tiga bulan adalah sebesar $5,5 \mathrm{~kg}$ dalam waktu tiga tahun pemakaian (Yayuk, 
2014). Dampak peningkatan berat badan pada akseptor KB suntik tiga bulan dapat menyebabkan gangguan kesehatan seperti Diabetes Melitus (DM) atau kencing manis, tekanan darah tinggi atau Hipertensi, migrain dan anemia bulan sabit (Sickle cell) sehingga diperlukan pemantauan / evaluasi untuk mencegah terjadinya penyakit sebagai akibat tidak langsung pengguna $\mathrm{KB}$ suntik tiga bulan (Affandi, 2011).

Pelayanan kontrasepsi yang diberikan di Puskesmas Kom Yos Sudarso adalah seperti $\mathrm{KB}$ suntik tiga bulan, Pil, intra uterin device (IUD), metoda operasi wanita (MOW) dan Implan. Berdasarkan hasil studi pendahuluan yang dilakukan peneliti di Puskesmas Kom Yos Sudarso, diketahui jumlah akseptor KB aktif tahun 2016 adalah sejumlah 689 jiwa, dimana akseptor KB suntik tiga bulan merupakan angka akseptor KB terbanyak sebesar 354 jiwa (51,37\%), diikuti Pil 317 jiwa, IUD 11 jiwa, MOW 4 jiwa, Implan 2 jiwa.

Berdasarkan hasil wawancara peneliti terhadap 10 orang akseptor KB suntik tiga bulan tentang efek samping yang dirasakan atau terjadi setelah penggunaan KB adalah kenaikan berat badan diikuti dengan kejadian Hipertensi sebanyak 9 akseptor dan Diabetes Militus (DM) 1 akseptor.

Hasil studi pendahuluan yang dilakukan oleh peneliti dari hasil penimbangan berat badan dan melihat kartu KB akseptor di ketahui bahwa seluruh akseptor (10 orang) yang mengeluh mengalami peningkatan $\mathrm{BB} 1-3 \mathrm{~kg}$ setelah 2-3 kali penyuntikan. Sehingga dapat disimpulkan bahwa efek samping peningkatan berat badan yang dialami Akseptor KB suntik tiga bulan di Puskesmas Kom Yos Sudarso Kota Pontianak mengakibatkan gangguan atau masalah kesehatan seperti Hipertensi dan Diabetes Militus yang beresiko menyebabkan kematian akibat stroke atau penyakit jantung.

Berdasarkan uraian di atas maka peneliti tertarik untuk melakukan penelitian dengan judul "Perbedaan Antara Berat Badan Sebelum dan Sesudah Menggunakan KB Suntik Tiga Bulan di Puskesmas Kom Yos Sudarso Kota Pontianak Tahun 2016-2017”.

\section{Metode}

Penelitian ini menggunakan desain penelitian analitik komparatif, dengan pendekatan retrospektif. Penelitian dilakukan di Puskesmas Kom Yos Sudarso Kota Pontianak dari bulan Maret sampai Mei 2017. Populasi dalam penelitian ini adalah jumlah seluruh akseptor baru $\mathrm{KB}$ suntik tiga bulan periode bulan Januari sampai Desember 2016 sebanyak 354 orang.

Total sampel dalam penelitian ini adalah sebanyak 78 orang Akseptor KB suntik tiga bulan setelah 1 tahun atau lebih penggunaan dengan kriteria akseptor $\mathrm{KB}$ suntik tiga bulan Tahun 2016, Akseptor aktif KB suntik tiga bulan setelah 1 tahun atau lebih penggunaan dengan data rekam medik tersedia di Puskesmas Kom Yos Sudarso menggunakan rumus slovin. Pengambilan sampel secara nonprobability sampling dengan menggunakan metode sampling kuota (Saryono, 2011). 


\section{Hasil dan Pembahasan}

Tabel 1. Distribusi Frekuensi Berat Badan Sebelum Menggunakan KB Suntik

\begin{tabular}{cc}
\hline Berat Badan dalam kg & $\mathrm{N}$ \\
\hline $35-40$ & 11 \\
$41-45$ & 14 \\
$46-50$ & 26 \\
$51-55$ & 14 \\
$56-60$ & 11 \\
$61-65$ & 0 \\
$66-70$ & 2 \\
Total & 78 \\
\hline
\end{tabular}

Berdasarkan tabel 1 diketahui dari 78 akseptor yang menggunakan $\mathrm{KB}$ suntik tiga bulan berat badan yang paling tinggi $69 \mathrm{~kg}(1$ orang), berat badan paling rendah $35 \mathrm{~kg}$ (1 orang) dan berat badan yang terbanyak $50 \mathrm{~kg}$, dengan berat badan dari $35-40 \mathrm{~kg}$ (11 orang), 41-45 kg (14 orang), 46-50 kg (26 orang), 51$\mathrm{kg}$ (14 orang), 56-60 kg (11 orang),61-65 kg (0) dan 66-70 kg (2 orang).

Menurut BKKBN (2002) berat badan adalah salah satu parameter yang memberikan gambaran massa tubuh. Berat badan juga digunakan untuk mengklasifikasikan status gizi seseorang dimana berat badan kurang dipengaruhi oleh beberapa faktor seperti kurang makan, psikologis dan ginetik.

Menurut peneliti banyaknya berat badan responden yang dibawah $40 \mathrm{~kg}$ sebanyak 11 orang dalam penelitian ini dikarenakan ketidaktahuan akseptor atau kurangnya informasi tentang berat badan ideal yang berbeda untuk setiap orang sesuai dengan index masa tubuh (IMT), serta kurangnya konseling yang diberikan pada akseptor KB.

Hasil penelitian ini didukung oleh penelitian yang dilakukan Haryani Tahun 2010 tentang "Pengaruh Frekuensi Kontrasepsi Suntik DMPA Terhadap Kenaikan Berat Badan Pada Akseptor Kontrasepsi DMPA”, penelitian menunjukan bahwa berat badan akseptor sebelum menggunakan $\mathrm{KB}$ adalah paling rendah $40 \mathrm{~kg}$ dan paling tinggi $70 \mathrm{~kg}$.

Penelitian diatas sependapat dengan penelitian Purwanti tentang "Analisis Perbedaan Berat Badan Sebelum dan Selama Menggunakan KB Suntik Tiga Bulan di BPS Ny, Ismiati Desa Jatirunggo, Kecamatan Pringapus, Kabupaten Semarang" mengakatan bahwa berat badan rata-rata sebelum menggunakan KB suntik tiga bulan adalah 46,2 $\mathrm{kg}$. Menurut peneliti penjelasan atau penapisan perlu dilakukan pada akseptor yang akan melakukan KB suntik tiga bulan dikarenakan ada 11 orang akseptor yang memiliki berat badan dibawah $40 \mathrm{~kg}$.

Tabel 2. Distribusi Frekuensi Berat Badan Sesudah Menggunakan KB Suntik Tiga Bulan

\begin{tabular}{cc}
\hline Berat Badan dalam kg & $\mathrm{N}$ \\
\hline $38-40$ & 3 \\
$41-43$ & 5 \\
$44-46$ & 7 \\
$47-49$ & 11 \\
\hline
\end{tabular}




\begin{tabular}{cc}
\hline \hline $50-52$ & \\
\hline $53-55$ & 15 \\
$56-58$ & 12 \\
$59-61$ & 8 \\
$62-64$ & 8 \\
$65-67$ & 5 \\
$68-70$ & 1 \\
$71-73$ & 2 \\
Total & 1 \\
& 78 \\
\hline
\end{tabular}

Berdasarkan tabel 2 tentang distribusi frekuensi berat badan sesudah menggunakan KB suntik tiga bulan di Puskesmas Kom Yos Sudarso Kota Pontianak, diketahui dari 78 akseptor yang menggunakan $\mathrm{KB}$ suntik tiga bulan berat badan yang paling tinggi $73 \mathrm{~kg}$, berat badan yang paling rendah $38 \mathrm{~kg}$ dan yang paling banyak $52 \mathrm{~kg}$, dengan berat badan 38-40 $\mathrm{kg}$ (3 orang), 41-43 kg (5 orang), 44-46 kg (7 orang), 47-49 kg (11 orang), 50-52 kg (15 orang), $53-55 \mathrm{~kg}$ (12 orang), 56-58 kg (8 orang), $59-61 \mathrm{~kg}$ (8 orang), 62-64 kg (5 orang), 65-67 $\mathrm{kg}$ (1 orang), 68-70 kg (2orang) dan 71-73 kg (1 orang).

Hasil penelitian berat badan sebelum menggunakan KB suntik tiga bulan didapatkan berat badan akseptor dibawah $40 \mathrm{~kg}$ sebanyak 11 orang namun setelah menggunakan $\mathrm{KB}$ suntik tiga bulan berat badan dibawah $40 \mathrm{~kg}$ menjadi 3 orang yang artinya sebagian besar akseptor mengalami kenaikan berat badan.

Hal ini sesuai dengan teori Hartanto Tahun 2004 Kenaikan berat badan merupakan kelainan metabolisme yang paling sering dialami akseptor KB. Perubahan kenaikan berat badan ini dapat di pengaruhi oleh berbagai faktor seperti faktor hormonal yang terkandung dalam kontrasepsi suntik yaitu hormon progesteron.
Kenaikan berat badan pada akseptor KB suntik tiga bulan akan mempermudah perubahan karbohidrat menjadi lemak dan disimpan dibawah kulit, sehingga lemak subkutan bertambah dengan merangsang hormon nafsu makan yang ada di hipotalamus karena adanya nafsu makan yang lebih banyak dari biasanya tubuh akan kelebihan zat-zat gizi dan penurunan aktivitas fisik oleh hormon progesteron

Hasil penelitian ini didukung juga oleh teori Arum Tahun 2009 menyatakan bahwa peningkatan berat badan tidak terlalu besar, bervariasi antara kurang dari $1 \mathrm{~kg}$ sampai $5 \mathrm{~kg}$ dalam tahun pertama penggunaan KB suntik tiga bulan. Hasil penelitian ini diperkuat oleh penelitian terdahulu yang dilakukan oleh Rumende Tahun 2015 tentang Evaluasi Penggunaan Kontrasepsi Suntik Pada Pasangan Usia Subur (PUS) di Kelurahan Walian I Tomohon. Responden yang mengalami perubahan berat badan yaitu 50 responden dari 62 responden $(80,65 \%)$. Pada penggunaan $\mathrm{KB}$ suntik tiga bulan berat badan bertambah $2,3 \mathrm{~kg}$ pada tahun pertama. Hal tersebut menunjukan bahwa ada pertambahan berat badan pada akseptor KB suntik tiga bulan setelah tahun pertama penyuntikan.

Hasil penelitian ini juga didukung oleh penelitian yang dilakukan Fatrina Tahun 2011 
tentang "Gambaran Perubahan Berat Badan

Pada Akseptor KB Suntik 3 Bulan di Kelurahan

Simomulyo Kecamatan Sukomanunggal

Surabaya", penelitian menunjukkan bahwa ibu yang menggunakan $\mathrm{KB}$ suntik 3 bulan sebagian besar $(63,1 \%)$ mengalami kenaikan berat badan, sebagian kecil $(15,8 \%)$ berat badan tetap, dan sebagian kecil (21\%) mengalami penurunan berat badan.

Menurut asumsi peneliti penggunaan kontrasepsi suntik tiga bulan menyebabkan perubahan berat badan, perubahan berat badan pada setiap akseptor berbeda, namun perbedaan kenaikan berat badan itu hampir terjadi diseluruh responden. Untuk itu diperlukan deteksi, seperti: pemeriksaan kadar gula darah dan pemeriksaan tekanan darah untuk mengetahui akseptor tersebut ada riwayat diabetes militus (DM), atau tekanan darah tinggi.

Tabel 3 Distribusi Frekuensi Berdasarkan Rata-Rata Berat Badan Akseptor Sebelum dan Sesudah Penggunaan KB Suntik Tiga Bulan

\begin{tabular}{crrrrc}
\hline Berat Badan dalam kg & Mean & N & Max-Min & Standar Deviasi & 95\% CI \\
\hline Sebelum & 48,67 & 78 & $69-35$ & 6,810 & $47,13-50,20$ \\
Sesudah & 52,77 & 78 & $73-38$ & 7,225 & $51,14-54,40$ \\
\hline
\end{tabular}

Berdasarkan tabel 3 di atas diketahui bahwa berat badan akseptor yang ada di Puskesmas Kom Yos Sudarso Kota Pontianak rata-rata sebelum diberi suntikan $\mathrm{KB}$ adalah $(48,67 \mathrm{~kg})$ dan rata-rata sesudah diberikan suntikan $\mathrm{KB}$ adalah $(52,77 \mathrm{~kg})$. Yang berarti rentang antara rata-rata berat badan sebelum dan sesudah menggunakan KB suntik tiga bulan adalah $(4,1 \mathrm{~kg})$.

Tabel 4. Perbedaan Berat Badan Akseptor Sebelum dan Sesudah Menggunakan KB Suntik Tiga Bulan

\begin{tabular}{cccccccr}
\hline Berat badan & Mean & Std. Deviasi & Std. Eror mean & df & T & P value & IC $=95 \%$ \\
\hline $\begin{array}{c}\text { Sebelum } \\
\text { Sesudah }\end{array}$ & \multirow{2}{*}{4,103} & \multirow{2}{*}{2,271} & .257 & 77 & $-15,953$ & \multirow{2}{*}{, 000} & $-4,615$ \\
& & & & & & &
\end{tabular}

Berdasarkan tabel 4 di atas diketahui bahwa rata-rata perbedaan antara berat badan akseptor yang ada di Puskesmas sebelum dan sesudah pengunaan $\mathrm{KB}$ suntik tiga bulan di Puskesmas Kom Yos Sudarso Kota Pontianak adalah $(-4,103)$ dan standar eror rata-rata perbedaan $(0,257)$.

Hasil uji t didapatkan nilai $\mathrm{t}$ hitung $=(-$ $15,953)$ dan $\mathrm{t}$ tabel $=(1,994)$ dengan derajat kebebasan $(\mathrm{df})=\mathrm{n}-1=78-1=77$. Hasil uji statistik diperoleh dari nilai $\mathrm{p}$ value untuk uji dua sisi (2 tailed) adalah 0,001. Maka dapat disimpulkan bahwa ada perbedaan antara berat badan sebelum dan sesudah pengunaan $\mathrm{KB}$ suntik tiga bulan di Puskesmas Kom Yos Sudarso Kota Pontianak. Menurut peneliti perbedaan antara berat badan sebelum dan sesudah menggunakan KB suntik tiga bulan di Puskesmas Kom Yos Sudarso Kota Pontianak yaitu kenaikan berat badan. Dari rata-rata berat 
badan sebelum menggunakan KB suntik yaitu sebesar 48,67 kg, dan sesudah menggunakan KB suntik menjadi $52,77 \mathrm{~kg}$ yang berarti rentang antara berat badan seebelum dan sesudah menggunakan $\mathrm{KB}$ suntik tiga bulan adalah $4,1 \mathrm{~kg}$.

Hasil pelitian ini didukung oleh teori Hartanto (2004), menyatakan bahwa kenaikan berat badan pada akseptor $\mathrm{KB}$ suntik karena pengaruh hormone progesterone yang merangsang pusat pengendalian nafsu makan dihipotalamus yang menyebabkan akseptor makan lebih banyak daripada biasanya. Menurut teori Djafar (2015) ada beberapa faktor yang mempengaruhi berat badan seperti: kelebihan makanan, kekurangan aktifitas, kemudahan hidup, Psikologis dan ginetik, Pola konsumsi makanan, kebudayaan dan faktor hormonal.

Penelitian ini sependapat dengan Purwanti Tahun 2015 tentang Analisis Perbedaan Berat Badan Sebelum dan Selama Menggunakan KB Suntik Tiga Bulan di BPS Ny, Ismiati Desa Jatirunggo, Kecamatan Pringapus, Kabupaten Semarang. Berat badan rata-rata sebelum menggunakan $\mathrm{KB}$ suntik tiga bulan adalah $46,2 \mathrm{~kg}$, selama menggunakan tiga bulan $\mathrm{KB}$ berat badan rata-rata $50,0 \mathrm{~kg}$, dengan berat badan terendah $40 \mathrm{~kg}$, dan tertinggi $60 \mathrm{~kg}$, berdasarkan hasil analisis menggunakan Paired $T$ Tes di dapatkan $p$ value $=0,000<0,05$, berarti ada perbedaan berat badan sebelum dan selama menggunakan KB suntik tiga bulan di BPS Ny. Ismiati Desa Jatirunggo, Kecamatan Pringapus, Kabupaten Semarang.

\section{Kesimpulan}

Berdasarkan Analisis Data Dan

Pembahasan Hasil Penelitian Mengenai Perbedaan Anatara Berat Badan Sebelum Dan Sesudah Menggunakan KB Suntik Tiga Bulan

Di Puskesmas Kom Yos Sudarso Kota Pontianak Tahun 2016, Maka Dapat Diambil Kesimpulan Bahwa Ada Perbedaan Berat Badan Akseptor Sebelum Dan Sesudah Penggunaan KB Suntik Tiga Bulan Di Puskesmas Kom Yos Sudarso Tahun 2016 Dimana P Value $=0,000$ Yang Berati Ada Perbedaan.

Saran Untuk Tenaga Kesehatan Di Puskesmas Kom Yos Sudarso Agar Memberikan Penyuluhan Terhadap Pasangan Usia Subur (PUS) Untuk Memilih Alat Kontrasepsi Yang Tepat Agar Dapat Dijadikan Dasar Pertimbangan Dalam Penapisan Pada Calon Akseptor KB Baru Suntik Tiga Bulan.

\section{Daftar Pustaka}

Affandi Biran, Koesno Harni, dkk. 2011. Buku Panduan Praktis Pelayanan Kontrasepsi. Jakarta: PT Bina Pustaka Sarwono Prawirohardjo

Arum Setya Noviawati Dyah, Sujiyatini. 2009. Panduan Lengkap Pelayanan KB Terkini. Jogjakarta: Mitra Cendikia Offset

Djafar Azhari Azrul Muh. 2015. Laporan Tutorial Modul II Endokrin dan Metabolik Kegemukan. Falkutas Kedokteran: Universitas Muslim Indonesia

Fatrina. 2011. Gambaran Perubahan Berat Badan Pada Akseptor KB Suntik 3 Bulan Dikelurahan Simomulyo Kecamatan Sukomanunggal Surabaya. Akademi Kebidanan 
Hanim, Diffah. 2004. Pengkajian Penentuan Status Gizi Studi Obesitas Pada Wanita Usia Subur 20-45 tahun: Sekolah Pascasarjana Institusi Pertanian Bogor

Hartanto Hanafi. 2004. Keluarga Berencana Dan Kontrasepsi. Jakarta: Pustaka Sinar Harapan

2010. Keluarga Berencana Dan Kontrasepsi. Jakarta: Pustaka Sinar Harapan

Hartanto Huriawati, Wulansari Pita. 2007. Ragam Metode Kontrasepsi. Jakarta

Hermawanto Hery. 2010. Biostatistik Dasar. Jakarta: EGC

Irianto, Koes. 2014. Gizi Seimbang Dalam Kesehatan Reproduksi (Balanced Nutrion I Reproductive Health). Bandung: ALFABETA

Khomas. 2004. Peranan Pangan dan Gizi Untuk Kualitas Hidup. Jakarta: Gramedia Widiasarrana Indonesia

Mujiati Inti, Budijanto Didik, dkk. 2013. Buletin Jendela Data Dan Informasi Kesehatan Situasi Keluarga Berencana Di Indonesia. Bakti Husada

Notoatmodjo Soekidjo. 2012. Metodologi Penelitian Kesehatan. Jakarta: PT Rineka Cipta

Profil Kesehatan Indonesia.2014. profilkesehatan-indonesia-2014.pdf-adobe reader, diakses: 11 maret 2017 jam 10:20 WIB

2015. Kesehatan Keluarga. profil-kesehatan-indonesia-2015.pdfadobe reader, diakses: 11 maret 2017 10:40 WIB

Purwanti, dkk. 2015. Analisis Perbedaan Berat Badan Sebelum Dan Selama Menggunakan KB Suntik 3 Bulan Di BPS Ny. Ismiati Desa Jatirunggo Kecamatan Pringapus Kabupaten Semarang. Akademi Keperawatan Ngudi Waluyo Ungaran
Rahmawati Ita, Norazizah Yayuk. 2014. Survey Penambahan Berat Badan Pada Akseptor KB Suntik 3 Bulan Di Puskesmas Mayong I Kecamatan Mayong Kabupaten Jepara. Jurnal Kesehatan Budaya Hikmah Akbid Islam Al-Hikmah Jepara

Saratun, Maryani, dkk. 2008. Pelayanan Keluarga Berencana Dan Pelayanan Kontrasepsi. Jakarta: Trans Info Media

Saryono Setiawan Ari. 2011. Metodologi Penelitian Kebidanan DIII DIV S1 Dan S2. Yogyakarta: Nusa Medika

Siswanto, Susila dkk. 2014. Metodologi Penelitian Kesehatan Dan Kedokteran. Karanjeng Yogyakarta: Bursa Ilmu

Sugiyono. 2010. Statistika Untuk Penelitian. Bandung: Alfabeta CV

Nonparametris Untuk Penelitian. Yogyakarta: Alfabeta CV

Suharjo B Cahyono. 2008. Gaya Hidup Dan Penyakit Modern. Yogyakarta

Tomy Perkasa. 2016. Gambaran Efek Samping Pada Akseptor Kontrasepsi Hormonal Di Puskesmas Colomadu 2 Kabupaten Karanganyar.1268_naskah_publikasi.pdf, diakses: 9 maret 15:00 WIB

Uliyah Mar'atur. 2010. Panduan Aman Dan Sehat Memilih Alat KB. Yogyakarta: PT Bintang Pustaka Abadi (BiPA)

Yayuk Norazizah, Rahmawati Ita. 2014. Survey Penambahan Berat Badan Pada Akseptor KB Suntik 3 Bulan Di Puskesmas Mayong I Kecamatan Mayong Kabupaten Jepara. 17-33-1-SM.pdf, diakses: 9 maret 2017, 09.30 WIB 